\title{
AbSence Of A Common Kashmiri Identity And Future Claims In The Region Of KASHMir: PARAdox Of Distinct Nationalisms
}

Arzu GÜLER ${ }^{1}$

\begin{abstract}
Absence of a common Kashmiri identity and future claims complicates the resolution efforts for the Kashmir conflict and thus deserves a close examination. An ethnic triangle in the state of Jammu and Kashmir between the regions of Ladakh, Jammu and Kashmir prevents the emergence of a common Kashmirian identity. Furthermore, it is not possible to argue a common Kashmiri identity and future claims among the Muslims in the region of Kashmir. That's why; this study focuses on the reason of the absence of a common Kashmiri identity and future claim in the region of Kashmir and argues that religion is a separative factor rather than a unifying one among the Kashmiri Muslims and creates two distinct nationalisms: Secular and religious nationalism, which are encouraged further by the Indian and Pakistan policies.
\end{abstract}

Key Words: Kashmiri identity, religion, India and Pakistan.

\section{KEŞMİR BÖlgeSINDE ORTAK BİR KeŞMİR KIMLIĞININ VE GELECEK TALEPLERINI OLMAMASI: FARKLI MilliYetçILIKLERÍN PARADOKSU}

Özet

Ortak bir Keşmir kimliğinin ve gelecek taleplerinin olmaması Keşmir sorunun çözüm çabalarını zorlaştırmakta ve dolaylstyla derin bir incelemeyi hak etmektedir. Cammu ve Keşmir eyaletinde bulunan Ladak, Cammu ve Keşmir bölgeleri arasındaki üçlü durum ortak bir Keşmir kimliğinin oluşmasına engel olmaktadır. Dahası, Keşmir bölgesindeki Müslümanlar arasında da ortak bir Keşmir kimliği ve gelecek talebinden söz etmek mümkün değildir. Bu nedenledir ki; bu çalışma Keşmir bölgesinde neden ortak bir Keşmir kimliği ve gelecek talebinin olmadı̆̆ına odaklanmakta ve dinin Keşmirli Müslümanlar arasında birleştirici bir unsurdan ziyade ayrıştırıc bir unsur olduğunu ve iki farklı milliyetçiliğin oluşmasına sebep olduğunu iddia etmektedir: Hindistan ve Pakistan politikalarlyla desteklenen laik ve dini milliyetçilik.

Anahtar Kelimeler: Keşmir kimliği, din, Hindistan ve Pakistan.

\footnotetext{
${ }^{1}$ Yrd. Doç. Dr. Adnan Menderes Üniversitesi, İktisadi ve İdari Bilimler Fakültesi, Uluslararası İlişkiler Bölümü, arzuguler@adu.edu.tr
} 


\section{INTRODUCTION}

Kashmir conflict is a geopolitik conflict between India and Pakistan and is known as a longterm conflict in world politics. The princely state of Jammu and Kashmir under Indian control is composed of three regions: Ladakh with Buddhist majority, Jammu with Hindu majority and Kashmir Valley with Muslim pre-dominance ${ }^{2}$. However, even the Muslims in the region of Kashmir have different identities and claims for the resolution of that conflict. Questioning the reason for the absence of a common Kashmiri identity and future claims among Kashmiri Muslims, this study argues that religion has been a separative factor in the region of Kashmir and two distinct nationalism based on religion, secular and religious nationalism, emerged with the contribution of Indian and Pakistan policies.

The Kashmir region is one of the long term and unresolved disputes in the world. The problem began with the independence of India on 15 August 1947 and the establishment of Pakistan as an Islamic State. Great Britain as a colonial power in the region decided that local states including the state of Jammu and Kashmir would decide to access either to India or Pakistan as relevant to their demography, religious and ethnic structure, geographical position and will of people. On August 1947, around 563 princely states managed to decide their future however people of Jammu and Kashmir found themselves in a dilemma.

The ruler of the State at the time of the Indian independency, Maharaja Hari Singh (18951961) wanted to gain time to get a chance of independency such as India and Pakistan. Thus the state of Jammu and Kashmir did not reach a decision for a while and this delay resulted in uprisings by the Pakistan-supported Muslims, who were defending an accession to Pakistan. India came to the help of Hari Singh to suppress this uprising and in return he signed the Instrument of Accession to India on 26 October 1947 against the will of Kashmir Muslims. Pakistan argued the invalidity of this instrument since it was against the popular will. After the armed struggle between India and Pakistan in 1947, UN Security Council adopted Resolution 47 on April 21, 1948 instructed for a plebiscite allowing Kashmir people to decide to unite either India or Pakistan. However today, UN Resolution has never been implemented, since India argued the Instrument of Accession as the legal decision. Today, two thirds of the region is under India control while one third of it is under Pakistan control. The latter part is called as Azad (Freedom) Kashmir by Pakistan and while India called the region as Pakistan occupied Kashmir.

The study is divided into three parts. In the first part, a possible common Kashmiri identity in the state of Jammu and Kashmir and specifically in the region of Kashmir is discussed. In the last two parts, reason of the absence of a common Kashmiri identity and future claims among Muslims in the region of Kashmir is questioned by focusing on the Indian and Pakistan policies.

\section{KASHMIRI IDENTITY}

The state of Jammu and Kashmir consists of three regions, namely Ladakh, Jammu and Kashmir. Ladakh is the region with relative Buddhist majority (50\%) while Muslims constitute $46 \%$ of the population. Jammu has a majority of Hindu (Dogras) population with 66\% and has a Muslim population with minority of $30 \%$. Kashmir is the most homogenous region with its Muslim majority of 95\% while a Hindu minority (Pandits) constitutes 4\% of the population. (BBC, In Depth Report) Buddhists in Ladakh are ethnically Tibetans, while Hindus of Jammu are Dogras, not Kashmirian. In addition to this, even Hindus in Jammu are ethnically different from Hindus in the Kashmir. (Varshney, 1992: 198-206) The three distinct regions are also different in terms of language. Jammu has the majority of Dogri-speaking Hindus, while Kashmir has predominantly Kashmiri-speaking Muslims and Ladakh has the majority of Ladakhi-speaking Buddhist (Tremblay, 1996-97: 479).

\footnotetext{
${ }^{2}$ Azad Kashmir and Gilgit-Baltistan are under the control of Pakistan, while Aksai Chin is under Chinese control.
} 
Regarding the religious and linguistic differences and concentrations, it might be observed that there is an "ethnic triangle" (Sharma, 2000: 28) in the state of Jammu and Kashmir. Despite the existence of that ethnic triangle, it is still controversial whether Kashmirians has regard themselves historically as one people and lived in peace. On the one hand, it is argued that Kashmirians are united thanks to the common understanding of the unique Kashmiri history and culture, called ethnic humanism (Cockell, 2000: 327). On the other hand, it is stated that "to talk about a common culture, a 'Kashmiriat', is to live in a make-believe world" (Sharma, 2000: 31) with the twentieth century. The latter argument has its strong roots by the notion that people of Kashmir are three groups divided by religion and language and have three distinct future dreams. Ladakh claims Union Territory Status, Jammu is reluctant to change the status quo which is legally being a part of India while Kashmir wants more autonomy. (Sharma, 2000: 32)

During the partition of India and Pakistan, the multiethnic population of the state of Jammu and Kashmir was forced to choose between a predominantly Muslim nation and a predominantly Hindu nation. Thus, a movement towards Kashmiri nationalism would be a great answer offering hope and security for the people residing in Kashmir. (Rozenberg, 2015: 21) However, it is hard to talk about a Kashmirian identity for the entire state of Jammu and Kashmir since it has three ethnically separable geographical regions. Due to this heterogeneous structure, Kashmiri nationalism is regarded to base on religion rather than a separate Kashmir ethnicity.

Contrary to the difficulties that prevent the emergence of a Kashmiri identity in the state of Jammu and Kashmir, the region of Kashmir seems to have conditions conducive for such a Kashmiri nationalism based on religion among its Muslim population (here after Kashmiri identity). Kashmir is a place, which is geographically isolated because of high mountains (from 10000 feet to 18000 feet high). This isolated situation may contribute the emergence of a Kashmiri identity with the help of well internal connection. For example, it is possible to reach from any corner of the Kashmir to any other requires just a few hours by car. These geographical isolation and well internal connections enabled Kashmir to maintain its social and cultural distinctiveness (Malik, 1992). In Kashmir, together with the common traditions and history, religion and language also contribute to the common culture besides the factor of geography. 95\% of the population belong to the same religion and the majority of Muslims speak Kashmiri as their mother tongue. Thus, it can be well argued that "a common language bound them closer into a distinct cultural grouping" (Naqash and Shah, 1997: $11)$.

However, it is not exactly known how Kashmiri Muslim people define their identity or how they prefer to be called. The reason for this uncertainty is the failure of holding a plebiscite in the region of Kashmir. In the post-1953 period when Primer Minister of Jammu and Kashmir, Sheikh Abdullah (1905-1982), was arrested, Kashmiri identity politics became increasingly nationalist. Replacing the National Conference, the Plebiscite Front was established to provide a political vision to Kashmiri people. By the end of 1980s, there was a transformation of Kashmiri demands from autonomy into sovereignty and freedom from the Indian State. The elections in 1987 were rigged, though not the first one, and particularly young generation of Kashmiris felt politically alienated and isolated. This feeling led an increasing demand of secession and the "Kashmirian identity got fractured and got manifested differently by different political groups and organizations, depending upon their goals and strategies" (Bhat, 2014: 34). While secular nationalists in the region of Kashmir prefer to be under the administration of a secular Indian administration or demand an independent and secular Kashmir, religious nationalists prefer to establish an independent Islamic Kashmir or demand accession to Pakistan. Thus, religion became a separative factor among the Muslims in the region of Kashmir rather than a unifying factor that may create a common Kashmiri identity. That's why; this study focuses on the reasons of the absence of a common Kashmiri identity in the region of Kashmir and finds out that distinct nationalism in Kashmir, namely secular and religious nationalism supported by Indian and/or Pakistan policies, may explain the absence of a common Kashmiri identity. 


\section{SECULAR NATIONALISM}

According to Naqash and Shah (1997: 10), "Kashmiriat is a sense of community of the people who have lived together for ages and developed and preserved its own distinct identity. It is beyond the religion." They argue that both Muslims and Pandits in Kashmir have established different methods of practising of their faith, traditions and symbols which make them distinct from their coreligionists. It is this distinctiveness, which create a common Kashmiriat in Kashmir. Kashmiri people are unlikely to identify their Kashmiri identity with Islam (Puri, 1995). According to Bhat (2014: 32), Kashmiriat is evolved by absorbing diverse cultural elements and different religious practices such as Buddhism, Shaivisim, Jainism and Islam. Cockell (2000: 327) argues that since Kashmiri Muslims and Pandits share many cultural practices, it is the term of ethnic humanism, which is the common understanding of the unique Kashmiri history and culture, which unites all Kashmirians regardless of religion.

Secular nationalism in the Kashmiri identity finds its best example in the history of the Kashmir conflict during the 1930s. In 1934, Maharaja Hari Singh (1895-1961) promulgated the new Constitutional Act, which restricted government employment to the citizens of the State and provided the right of citizenship only to a limited section of the population. The best beneficiaries of this Act are the small middle classes, which were Jammu's educated Dogras and the Kashmiri Pandits. In order to protest this discriminative situation, Indian statesman Sheikh Abdullah organized a Muslim Conference in 1931, which would then be transformed into a National Conference as a mass-based, secular and socialist nationalist movement against the Dogra rule in 1939. The reason of such a transformation was to expand the membership of the Muslim Conference and to have a secular and nationalist ideology. Thus, instead of religious unity, Sheikh Abdullah and other Kashmiri nationalist leaders emphasized the idea of Kashmiriat. (Arakotaram, 2009: 34) According to Tramblay (1996-97: 480), "this nationalist movement established the nature and boundaries of the Kashmir nation." This secular and nationalist understanding of Kashmiri identity rejected the formula that Muslims and Hindus form separate nations. Instead of regarding religion as a determining factor, Sheikh Abdullah considered his movement not only for Muslims but also for Hindus who suffered from the Dogra rule. (Sharma, 2015: 162) However, this pro-Indian stance in terms of Kashmiri identity transformed into a Kashmiri movement for self-determination due to the failure to gain support of the minority communities of Hindus and Buddhists and due to the dominance of the Hindu-majority in India (Varshney, 1991).

Secular nationalists in Kashmir support for either independency or being under the administration of a secular Indian state. The main reason of Kashmiri secular nationalists' feeling of alienation from Pakistan lies on the Pakistan-backed violence within Kashmir. The fundamentalist insurgent groups in Kashmir have used violence against Pandits and against secular Muslims, who have relations with Indian secularism and these insurgent groups are arguably under the political and technical support of Pakistan. (Cockell, 2000: 331)

The Azadi (freedom) nationalism is defined by two primary factors, namely the social and cultural identity and the common history (Cockell, 2000: 326). The main organisation for the support of an Independent State of Kashmir is Jammu and Kashmir Liberation Front (JKLF). Founded in 1964 but emerged as the most prominent armed group of insurgency in 1989, the Front advocates independence, secularism and self-determination for the entire state of Jammu and Kashmir also including Pakistan-held Kashmir and Gilgit-Baltistan. A senior figure within the pro-independence JKLF stated in 1994: “(...) our Kashmiriat culture is unique, our customs and way of life are unique. We feel Kashmir is our own country. (...) We want to build our own country, in our own way, according to our own culture.” (Cockell, 2000: 327) Since 1994, JKLF adopted peaceful means such as a political and diplomatic strategy rather than a military one to pursue its goal of self-determination for Kashmiris (Anant, 2009: 762). While JKLF has taken large support from Kashmiri Muslims, Hindus question the Front and view the separatist movement within a global context of Islamic fundamentalism (Tremblay, 1996-97: 472). Actually, JKLF identified itself as an anti-colonial national Muslim liberation movement but not Islamist and argues to derive its legitimacy from 
largely secular Kashmiris. Anant (2009:762) states that "many Hindus were killed because they were opposed to the JKLF's cause, not solely because they were Hindus."

Indian secular policies also encouraged the secular nationalism also in Kashmir. India has tried to keep a balance between formal and informal nationalism in Kashmir. The aim has been to create a new identity among Muslims based on similarities between India and Kashmir such as socialism, secularism and democracy. Thus, the similarities between Kashmir and Indian state are based on the socialistic and democratic agenda (Tremblay, 1996-97: 486-487). While the similarities have been put forward, the differences between Kashmir and Indian state such as religion have been disregarded. India stressed the concept of 'Kashmiriat' during the process of nation building during the integration of the princely states into the nation state in 1947. Although Indian aim was to provide for the people of Kashmir a psychological satisfaction from future vulnerabilities of assimilation (Shah, 2014: 7), it affected the process of constructing and maintaining collective identities by naming the Kashmiri identity and by creating legal categories such as Article 370 in which there have been references to Kashmiri citizens.

Indian national movement led by the Congress Party claims that Muslims are equal citizens of India such as Hindus. This is the notion of rejecting two nations theory, which means two distinct religious groups equal to two separate national groups ${ }^{3}$ (Majid, et.al., 2014). According to the supporters of Indian secular nationalism, a proof of the failure of this theory is the Instrument of Accession. It arguably shows the Indian secularism as independent from the factor of religion. In fact, two nations theory constitutes a threat for India since it is a mosaic of different ethnically heterogeneous groups. A fragmented population has the threat of ethnic violence and even separatism. Considering this, a possible Kashmiri secession would mean a possible Hindu-Muslim conflict in North and East India. Thus, Varshney (1992: 203) argues that "not only is Kashmir as a prisoner of the longer context. Even those wanting communal peace in India have become prisoners of Kashmir." The importance of Kashmir lies on the fact that it is the only Muslim-majority state in India and the Kashmir conflict had a great impact on the Muslim identity in the mainland India. Thus, the Indian secularists consider Kashmir accession to India as a part of Indian foundation due to its eventual support of the notions of secularism, democracy, federalism and nationalism. (Sharma, 2015: 160)

Underlying its secular character, India has sought a policy of state-sponsored nationalism. The aim is to maintain the dual identity of Kashmiri population under the high values of socialism, secularism and democracy. According to Tremblay (1996-97: 476-478), India has pursued three basic policies for such an aim. The first one is the process of political construction of identity through legal and constitutional structures. To that end, India has focused upon the secular ethnic identity of Kashmiriat. The second one is the sub-state sphere of the representation by which India have supported any opposition allowing pressures from the margin on the ruling party and by which India have pursued to maintain patronage politics. The third one is the state strategy to suppress popular nationalism. However, in Kashmir, disabilities of political system such as the lack of a competitive party system and maintenance of patronage politics at the expense of development have created challenges against accession to India. As a result, Indian policy of state-sponsored nationalism has failed.

\section{RELIGIOUS NATIONASLISM}

Madan (1998: 984-986) supports that the religious difference creates different perceptions in the population of Kashmir. The Hindus are misbelievers in Muslim perception and the Muslims are impure in the Hindus perception. Thus, there is not a key symbol of collective identity other than religion to mobilize support. Malik (1992) supports the crucial role of religion by stating that the Kashmiri Muslims constitute religion as their distinct identity. Shah (2014: 2) also stresses the role

\footnotetext{
${ }^{3}$ This theory was the basis of Pakistani argument when declaring independency in 1947 and failed in explaining the establishment of Bangladesh as a predominantly Muslim state.
} 
of Islam as being the main cultural identity for the majority of the people since the evolution of different identity was structured by Islam and local culture. However, the Kashmiri Muslims are also not homogeneous by having divided between Sunni and Shia sects and by being supporter of moderate or radical Islam. This division in Kashmir is also encouraged by the Indian and Pakistan policies.İktisat bölümünde eğitim gören öğrencilerin iktisat bölümünü seçme nedenleri ve bölümün beklentilerini karşılama düzeyinin belirlenmesinin yanında, öğrencilerin tanımlayıcı özelliklerine göre öğrencilerin iktisat bölümü seçme nedenleri ve bölümün beklentilerini karşılama düzeyinde farklılaşma olup olmadığının incelenmesi amacıyla Ömer Halisdemir Üniversitesi İktisadi ve İdari Bilimler Fakültesi'nde 2016-2016 eğitim öğretim yılında iktisat bölümünde eğitim gören 503 öğrenci üzerinde gerçekleştirilen araştırmadan aşağıdaki sonuçlara ulaşılmıştır:

The Muslim Conference was a result of religious leaders’ declarations in Jammu and Kashmir on the attack against Islam. "Destruction of a mosque, interruption of a sermon, and the desecration of a Quran" in July 1931 created such a threat perception, responded by the Dogra regime's jailing of the 7000 Muslims. The events led the formation of the All-India Jammu and Kashmir Muslim Conference with the intention of politically organizing Kashmir Muslims. In return, the Muslim political movement created a threat perception among the Hindu leaders towards a Muslim domination. (Arakotaram, 2009: 32)

Furthermore, the emphasis of Hindu nationalists within India, represented by Bharatiya Jarata Party (BJP), on the Muslim disloyalty to India and their critics of the Muslim question as the reason of Indian division (Varshney, 1992: 197) caused the increase in religious nationalism in Kashmir and a division from secular nationalist Muslims. The main criticism point of the BJP is the establishment of Pakistan in 1947 and establishment of Bangladesh in 1971 as predominantly Muslim and independent states. In short, the question that Hindu nationalists ask is 'Muslims of pre-1947 India already have two homelands and would Kashmir be a third?' Thus, Hindu nationalists argue that Muslims, as being a separate national group, are not an integral part of the Indian nation and should be subordinated under Hindu dominance. That's why; the Hindu religious nationalism constitutes one of the reasons of Kashmiri Muslims' distrust towards Indian secularism by creating a feeling of threat among Muslims that their rights would be limited.

It might be argued that India has ignored the claims of Kashmir Hindus regarding an eventual accession to India. According to Tremblay (1996-97: 489), the reason of this ignorance might be explained from two points of view. The first one was the Dogras who play a role in politics as the rulers of the State in times of monarchy. Since Kashmiri Muslims wanted to liberate themselves from Dogra Maharajas' oppressive rule, India did not 'cooperate' against the will of the Muslim population. The second reason was the Indian trust to the granted Jammu's loyalty. Consequently, the Kashmiri Hindus and Jammu Hindus aligned with Hindu fundamentalist groups such as BJP. This resulted in even sharpened the religious identities within the State and also led the construction of a legal Kashmiri identity by creating a 'Kashmiri other' in the eyes of Hindu nationalists. In return, this process increased the demands of autonomy by Kashmiri Muslims and led to further alienation and stronger claims for autonomy.

The policies of Indian government prevented the Kashmirians participation also to the democratic process in India by regarding elections in Kashmir as unfair and rigid. In return, this caused on the rise of militancy in Kashmir. (Cockell, 2000: 325) Thus, Indian mismanagement of political institutions played a role in the alienation of Kashmiri identity. Kashmirians have felt that their identity has been under threat due to the Indian policies and this threat perception was triggered by the "systematic human rights violations by Indian security forces" (Cockell, 2000: 328). From the Kashmiri perception, the main concern is the occupation of Kashmir by a foreign army (Dreze, 2000). Besides contributing to the alienation of Kashmiri Muslims from India, Indian policies have also led to the fundamentalist groups to support Pakistan, which would lead a further alienation of Kashmiri Muslims.

Beside the Indian policies that encouraged religious nationalism in Kashmir, Pakistan policies also triggered the division between religious and secular nationalism in the region. It might be well argued that Pakistan is founded on religious nationalism as being established with a predominantly Muslim state. During its establishment, 65 million Muslim joined Pakistan while 35 million were 
left behind in India. In 2015, the Muslim population in India reached to 180 million as forming the second-largest community (India Guide). Thus, the dilemma that Pakistan has faced is that if it tries to liberate Kashmir, Pakistan would risk the welfare of Muslims in India. If not, Pakistan would contradict with its founding principle of existence (Varshney, 1992: 196-200). As being a Muslim state in its core establishment reason, Pakistan tries to legitimate this reason of existence with the accession of Kashmir as a Muslim-majority region to Pakistan. With this aim, it tends to strengthen the religious side of Kashmiri identity and thus supports the fundamentalist militancy groups in Kashmir, which claim accession to Pakistan. According to Pakistan, "Kashmir conflict is an ongoing freedom struggle of Kashmiri Muslims against Indian occupying forces" (Ahuja, et.al., 2016: 2).Pakistani religious nationalism has been based on two nations theory arguing that Hindus and Muslims are two different religious countries and two separate nations. Still, a rising tendency of secular nationalism might have been observed in Pakistan against the fundamentalist Islamic nationalism. This modernist Islam began to develop in 1960s by rethinking of Islam. However, after the Islamic revolution in Iran in 1979, political Islam again raised. (Malik, 1999: 99)

The radicalization of Pakistan following the 1971 War "led some leaders in Kashmir to seek a separate homeland for the Kashmiri Muslims” (Sharma, 2015: 162). In 1971, when Bangladesh emerged as an independent predominantly Muslim state, the bargaining capacity of Pakistan decreased. Kashmiri Muslims stressed on a Bangla identity against the Paki identity, which showed the failure of two nations theory: Even one common religion might lead two separate nations. And religion might not be enough as an element of creating a common identity. However, Pakistan managed to gain support from the fundamentalist Kashmir Muslims in a wider range with a twofold strategy. Pakistan focused on both strengthening religious ties between two nations and on keeping the demand for plebiscite alive by using communication technology, first radio and then television. As the alienation of the Kashmiri Muslims increased by the Indian policies and its state-sponsored symbolism, the reliance on Pakistan-based political and religious information also increased (Tremblay, 1996-97: 490). As a result, the fundamentalist Kashmiri Muslims who are inspired of and backed by Pakistani policies have taken militancy policies, which led to further alienation of Kashmiri Muslims. Pakistan policy of continuous monitoring of the Kashmiri Muslim situation, interference in their affairs and privileges given to them resulted in two nationalisms, one is towards India and the other is towards Pakistan (Sharma, 2015: 164). Since JKLF had clear anti-Pakistan elements in its identity, Pakistan-supported armed groups in Kashmir Valley were proliferated, Hizbul Mujahidden (HM) being the largest one. HM was established in 1990 with the support of Pakistan to counter the pro-independence JKLF (Anant, 2009: 764). The Pakistan-supported insurgent movements argue either accession to Pakistan or an independent Islamic state having close relations with Pakistan. The fundamentalists regard the Hindu and Buddhist minorities as 'outsiders' and organise violent attacks against Buddhist in Ladakh and drive out Hindu families out of Kashmir.

\section{CONCLUSION}

Analysing ethnicity and nationalism in Kashmir is a challenging task due to the complexity of multiple dimensions. Consisting of three regions and having different religious and ethnic structures in each region, it might not be possible to argue a common Kashmiri identity for the entire state of Jammu and Kashmir. Ladakh has a Buddhist majority who are ethnically Tibetan and claims the Union Territory status, Jammu has Hindu majority and claims for the maintenance of existing relationship with India that is accession to India by the Instrument of Accession in 1947. Kashmir is pre-dominantly Muslim and Kashmiri Muslims have different claims on their future, namely establishing a secular or Islamic independent state, remaining under the administration of a secular Indian state or accession to Pakistan. Thus, while the ethnic triangle prevents the emergence of a common Kashmiri identity in the state of Jammu and Kashmir, it is similarly difficult to argue for a common Kashmiri identity in the region of Kashmir. Despite the existence of a common ground of religion, Kashmiri Muslims are separated among themselves on their future claims for the resolution of the Kashmiri conflict. Thus, this study attempts to question why religion became a separative factor in the region of Kashmir rather than a unifying factor among Kashmiri Muslims and finds out 
that distinct nationalisms in the region, namely secular and religious nationalism, supported by Indian and Pakistan policies, are the reason for the absence of a common Kashmiri identity and future claims.

Kashmiri Muslims might be divided into two groups. The first one is the secular Muslims who mostly support independency or support Indian secular nationalism. The other one is the fundamentalist Muslims who mainly support militancy insurgent groups. The latter claims for an Islamic state or for accession to Pakistan. The Indian and Pakistan policies trigger this split among the Kashmiri Muslims. On the one hand, Indian state-sponsored secular nationalism imposes proIndianness focusing on similarities between India and Kashmir such as socialism, secularism and democracy rather than highlighting the religious difference. This creates an alienation of fundamentalist Muslims and reaction of Hindu religious nationalists to the Indian secular nationalism contributes this alienation. On the other hand, Pakistan policy of support to the militancy insurgent groups such as Hizbul Mujahidden increases the alienation of secular Muslims from Pakistan. Thus, the Indian and Pakistan policies also complicate the conflict resolution further by triggering the division between secular and fundamentalist groups within the Kashmiri Muslims.

\section{REFERENCES}

Ahuja, K. \& Dhillon, M. D. \& Akalamkam, K. \& Papneja, D. (2016). Identities in Conflict: A Comparison of Drawings of Muslim Adolescents in Kashmir and Delhi. SAGE Publication, Retrieved January 19, 2016 from the World Wide Web: http://sgo.sagepub.com/content/spsgo/6/1/2158244015623596.full.pdf

Anant, A. (2009). Identity and Conflict: Perspectives from the Kashmir Valley. Strategic Analysis, 33(5), 760-773.

Arakotaram, K. (2009). The Rise of Kashmiriyat: People-Building in 20th Century Kashmir. The Columbia Undergraduate Journal of South Asian Studies, 1(1), 26-40. Retrieved October 15, 2015 from the World Wide Web: http://www.columbia.edu/cu/cujsas/Volume\%20I/Karan\%20Arakotaram\%20\%20Kashmiriyat.pdf

BBC News. The Future of Kashmir In Depth. Retrieved October 25, 2015 from the World Wide Web: http://news.bbc.co.uk/2/shared/spl/hi/south_asia/03/kashmir_future/html/

Bhat, S. (2014). Political Assertion of Kashmiri Identity. Global Journal of Multidisciplinary Studies, 3(6), 28-36.

Cockell, J. G. (2000). Ethnic Nationalism and subaltern political process: exploring autonomous democratic action in Kashmir. Nations and Nationalism, 6(3), 319-346.

Dreze, J. (2000). Kashmir: manufacturing ethnic conflict. Retrieved September 20, 2015 from the World Wide Web: www.hinduonnet.com/thehindu/2000/03/29/stories/05292523.htm

India Guide, Population of Muslims in 2015. Retrieved October 15, 2015 from the World Wide Web: http://www.indiaonlinepages.com/population/muslim-population-in-india.html

Madan, T.N. (1998). Coping with ethnicity in South Asia: Bangladesh, Punjab and Kashmir compared. Ethnic and Racial Studies, 21(5), 969-989.

Majid, A. \& Hamid, A. \& Habib, Z. (2014). Genesis of the Two Nations Theory and the Quaid-eAzam. Pakistan Vision, 15(1), 180-192.

Malik, I. (1992). Ethnicity and Contemporary South Asian Politics The Kashmir conflict as a case study. The Round Table, 81(322), 203-214. 
Malik, I. H. (1999). Islam, Nationalism and the West, Issues of Identity in Pakistan. Oxford: Palgrave Macmillan.

Naqash, N. \& Shah, G. M. (1997). Kashmir: From Crisis to Crisis. New Delhi: APH Publishing Cooperation.

Puri, B. (1995). The Kashmiriyat: The Vitality of Kashmiri Identity. Contemporary South Asia, 4(1), 55-63.

Rozenberg, N.P. (2015). Lessons from Kashmir: Is Eastern Ukraine Next? Challenged Decolonization and Compromised Identities. Bard College Senior Projects, 326. Retrieved December 25, 2015 from the World Wide Web: http://digitalcommons.bard.edu/cgi/viewcontent.cgi?article=1202\&context=senproj_s2015

Shah, M.A. (2014). Jammu and Kashmir: Understanding Identity and Difference. Retrieved September 22, 2015 from the World Wide Web: http://papers.ssrn.com/sol3/papers.cfm?abstract id=2541342

Sharma, R. (2000). Kashmir Autonomy (An Exercise in Centre-State Relations). Delhi: Shubhi Publications.

Sharma, R. (2015). India, Kashmir, and the Muslim Identity. CLAWS Journal, Retrieved September 25, 2015 from the World Wide Web: http://www.claws.in/images/journals_doc/1404273411_RituSharma.pdf

Tremblay, R. C. (1996-1997). Nation, Identity and the Intervening Role of the State: A Study of the Separative Movement in Kashmir. Pacific Affairs, 69(4), 471-497.

Varshney, A. (1991). India, Pakistan and Kashmir: Antinomies of Nationalism. Asian Survey, 31(11), 997-1019.

Varshney, A. (1992). Three Compromised Nationalisms: Why Kashmir Has Been A Problem. In R. T. (Ed.). Perspectives on Kashmir, The Roots of Conflict in South Asia (191-234). Boulder, CO: Westview Press. 